bowels and diarrhos, erysipelas, and congestion of the brain. Finese may be taken to represent the elfects of railway travel. ling, exposure to the weather. and excessive physial exertion conseguent upon the chutios of gurras. some of ihese men, now runniug from Lonclon to the Forth of Lugland and Seottis!: destinations, travel durino the year the astcundin: lis! ance-

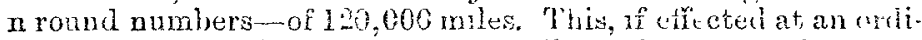
nary rate of travelling, say four teen miles an hour, would oc apy the whole of the 365 dars and nights of the year withriat coss tion; it would, in fact, he perpetual motion, and that at a tolerable speed. Douhtlews the leculiar effects of travellin is long distances upon railuxys, at it high rate of speed, are, so far as the above classes of railway chulop'; are concerned, consilerably modified by the active uature of therr huties, espe. cially in the case of guamis, who are incessantly employen either in mind or boriy, and who in the many stopprges of a long jurney are bourd to revder assistance to porters in the removel of hurgsage, ise, wad are thas relieved from the constraint and tedum of il lons and uneasy sitting position, which all passengers mois on less experience.

The books of this Suciery present sereral cases illustrative of the tendency of the membery occupation to induce brain disonters. The mos strilsin is thet of 3 ames $\mathrm{B}-$, furmerly a "conductor" rumbing from Lomon to Edinburght, an.l thenco b.ck to London, wisin an incerval of rest at each end of his

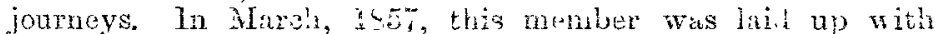
"severo cold," \&c., fur seven we 3 s, and agrin at the end of the following munth wis "cophatialgin and rheamatistil ;" and then in the Anost following he was certife.? as sufferius from "dyspepsia and overfingue from his ocunation." From this date he continued a clamant on the funis until Sept is:h, 1Sż, when lie cied. Fis medical certificates stateil thas he was suffering from "nervous debility," "nervous complaint," and "nervous irritation;" and having been certifed as inciruble under these circumstances, he was considercl entitled to the raluable benefit, $w^{2}$ lich $I$ belisve is peculiar to this Society alone-namely, full aick pay for life. For some time prior to his death he was confined in a luneic asylum; and it was well known and much spoken of at the time, as a decided case of insanity induced by excessive railway travelling. His journeys were about 40 miles each, repeat ed at intervals; the aggreyate in each year would be sbont 91,900 miles.

A inore recent instince, in one of the same class, may be unentioned, where a guard was temporarily disabled from "nervous irritation of the brain." Another, named Wlliam T_-, a few weeks since, on his journey to the North, was, after complaining of slight indisposition at starting, found dead in the carriage to whuth he had been removed. The canse of death I am unable to state, as the verdict of the Coroner's jury was-" Found dead."

These are a few of the more prominent cases, and if of any value to the ooject of your inquiries, you are welcome to their use. I am, Sir, yours, \&c.

Pailway Guards' Universal Friendly Society

29, Southamptun-buildings, Hulborn, FGb. 1862

Gromen Grosvenor General Sueretary.

\section{THE CAUSES AND EFFECTS OF RAPID CHANGES OF TEMPERATURE}

To the Editor of THE LANCET.

Srr,-As a frequent treveller upon the much-used suhurban line, - the West-end and Crystal Palace Railway,-I have to remark, that the public suffered in health last winter, and is likely to do so this next quarter, from the use of a peculiarly constructed second-class carringe, a very large undiviled on. nibus, with ten doors and windows, and glazed from end to eud on a level with the passangers' heads when seated. They were never originally intended to be used during the winter months, are ill-adapted to the season, and are the prolific cause of rheumatism of head, neck, and shoullers; of colds, toot hache, earache, influenza, bronchitis, pneumonia, \&c.; and for these reasons:One strong, hearty indivilual at the engine end of the carriage has command of his window, and will have it down; the conseguence is, that some forty.five or more passengers are placed in a cold, shivering draught of air many degrees below fretzing point. At every station all the travellers in these carridges are chilled and rechilled by passengers opening the doors for en tranee or exit. It will be quite obvious that by smaller com partments being substituted, much of this risk and danger to bealth would be done away with.

My experience with respect to the third class is, that passengers who viry likely get in heated from exercise or work, should have some kind of screen in seasons when the air, much below freezing, is wiffod acruss them with hurricane speet-a high wiml bein's ofren alded to the current of air induced by the rate at which the train is being propelled. On the continent a curtain of sailcloth is in use, and, if cheaper than ghas, should be at once supplied to the thircl-class passenger-cieriaces througheut the country by compulsion under an or ter emanains from the Goverment Luppotor of hallways, or the Smitary boarn, or the Boird of Tirulc.

The leating of trains by means of the waste steam passing throngl tubes carried beneath the verforate 1 flnoing of all the carriaces, wunli bo the greatest boon to the travelling priblic of these islands at such an inlospitable seasna as we experienced in the early part of last year. The low tempera ure of the carriages, especially on short lines, with frequent stoprages in populous districts, must bo the suarce of streat hetriment to publie heal.h, the passeugera not being alje to have with them a suffieiency of clothing for the very short time it is actnally required, compred with the length of time it would prove an incumbrance to husiness labits or to various exercises of boly from compulsion or for plotsure. The floors should be covered with gome non-conductor of heat till such time as the carriaces are heated by some means.

My experience is that, duriness is a very great and serious canse of nervons dismrbance, especially in children, and females of bysterical trayerament. I propose that the tunnels slould all be economically lighted, if only at intervals, and when trans are expected to enter snol dark chasms. Two gas-pipes shonll be ficsteved to the kering part of the arch, snd at intervils smaller tubts should drop fron the main trabes to abont a level with the npver mrt of the windows of the caringes, trs terminate in a closed claris-lantern with bull'seye glasses to concentrate ijght into the interior of the carriages whilst in tratsitu. If the trains are going at the rate of twenty-five miles an bour, a very few such lights would suffice, on the principle of the retina retaining, as it does, the inpression for an interval after the receipt of the image. By turuing the gits on or off the light might be made a means of sirnaling to allow trains to enter tannels, and having the linhts in dark-lanterns the glare would not bewilder the eyes of the riviver or cund. A cage fixed on the tops of the engine chimneys woull prevent large lighted cinders loing the dimage they do, and keep dust ont of the eyes of the passengers.

Upper Tooting, Feb. 1582.

I am, Sir, yours truly,

\section{ON THE PRESENT CONDITION OF RAILROADS. To the Eator of THE LAXCET.}

Sin,--I have read with great interest the remarks made in your article on "The Infuence of Railway Travelling upon Pnoilc Health" in THE LA CET of the 25 th ult. I cannot help thinking that the noise and jolting there alluded to, as being the great source of eril to travellers, are occasioned by a weak and enfeebled concition of the road. When railways were first projected, the engines weighed about ten or twelve tons, and trains ran at a speed averaging between twenty and thirty miles per bour. The roal at that time was, no donbt, adequate to the weights and speels run upon it. Now the engines weigh between thirty and thirty five tons, and trains are run at speeds of between fifty and sixty miles per hour, the road mean while remaining almost unaltered.

Mr. Hawkshaw, President of the Institution of Civil Engineers, in his opening address to that body the other evening, alluded to the fact that the road at present employed was incarable of sustaining the heavy weights and rates of speed now run upon it, and that the wear and tear, and consequently the annual expenditire for repairs, were enormons. If this be true, it may be inferred that with a hetter road we should have fewer accillents, less noise and rocking, and consequently more comfort in travelling. Craven-street, Strand, Feb. 1562. I am, Sir, yours, \&c.

\section{PAYMENT OF FEES TO POOR-LAW SURGEONS. To the Editor of Thr LANCET,}

Sir,-Will you allow me, through the columns of your pub. licxtion, to impress upon all medical officors and medical practitioners who have nccasion to render medical or surgical services to boards of guardians, the extreme importance of their apply. 